\title{
Forestry Activities that Forest Rangers Give Priority to in Seasonal Terms
}

\author{
İsmail Şafak*, Emre Göksu \\ Aegean Forest Research Institute, Urla, Izmir, Turkey
}

Received: 8 August 2019

Accepted: 15 October 2019

\begin{abstract}
Forest engineers and forest rangers fulfill the forest management activities considering the principle of efficiency and sustainability in Turkey. Forestry activities that forest rangers prioritized for each season were questioned in the study in accordance with the purpose of forest enterprises. The study was carried out in the Denizli Forest Enterprise Directorate in Turkey. The seasonal priority value of each activity performed in forestry departments was determined by the ranking technique. The ranking of most prioritized forestry activities on a seasonal basis was determined using the linear combination technique. As a result of analysis, the forestation, silviculture, production and marketing activities are given the highest priority in autumn, winter and spring seasons by forest rangers. Also, the activities of combating forest fires are given the highest priority during the summer season. The least priority is usually given to the activities in the non-wood forest products and services department. As a result, forest rangers' priorities for forestry activities differ according to the seasons.
\end{abstract}

Keywords: forestry activities, forest rangers, linear combination technique, ranking technique

\section{Introduction}

Forest resource management is a complex process comprising a large number of variables in the economic, social and environmental issues involved in the decision-making process. Forestry engineers and forest rangers are actively involved in the execution of technical, managerial and financial affairs for the management of these resources. In Turkey, the title of forest engineer is given to the people who graduated from the forestry engineering department of a forestry faculty. Forest rangers are required to have an associate degree education in one of the fields such as forest

*e-mail: isafak35@hotmail.com management, hunting and wildlife, seedlings and nonwood forest products.

Forest rangers, who are considered as the auxiliary technical staff, work under the forest engineers. The duties and responsibilities of the forest rangers were collected in 13 headings in Turkey [1]. These headings are as follows: i) the conservation of forest areas; ii) care and regeneration of forests; iii) conservation of forestation sites; iv) conservation of hunting and wildlife fields; v) production of wood raw materials; vi) production of non-wood forest products; vii) combating forest fires; viii) combating forest pests; ix) fighting against forest crimes (investigation and filing official reports); x) seed supply, forestation, arboriculture, soil preservation, and rangeland works; xi) surveillance and supervision of workers in the field; and xii) protection and care of guns, tools, and materials given to them. 
As can be seen, forest rangers do important and serious work on forestry issues. In addition, forest rangers undertake a role in facilitating communication in the implementation of forestry projects and transferring them to society.

Research related to the management of forest enterprises in Turkey generally reflects the views of the forest engineers. Y1lmaz et al. [2] determined the workload level of forest engineers. Kuvan et al. [3] explained the factors affecting the perception of forest administrators on basic forestry issues. Şafak and Göksu [4] determined the amount of job diversity in the Denizli Forest Enterprise Directorate. According to this, $14.1 \%$ (308 pieces) of the 2189 works performed by the forest enterprise directorate were carried out by forest rangers. Research on forest rangers is less than the amount of research on forest engineers. Maier and Winkel [5] examined the individual characteristics and personal perceptions of forest rangers within the scope of integrated forest management. Elvan [6] examined the duties and powers of forest rangers, and Öztürk [7] investigated the problems of forest rangers. Alkan and Uğur [8] investigated the training, problems experienced in the workplace and efficiencies of forest rangers.

As can be seen from the topics presented above, forest resource managers must take a large number of decisions affecting the long-term future of forest ecosystems and their daily activities. These decisions require consideration of the views of stakeholders involved in forestry and the use of multi-criterion decision-making approaches. In multi-criteria decision-making models, the value and preferences of stakeholders and decision makers can be taken into consideration [9]. For this purpose, sorting, grading, and binary comparison techniques are widely used in the evaluation of criteria and the emergence of preferences [10]. In this study, we used linear combination and ranking techniques.

Şafak and Gül [11] found that forest engineers in the Aegean region of Turkey prioritized 12 forestry functions and 13 forestry activities in February-March 2011. In this study, in preference to the importance level, it was seen that the effects of the current season were dominant, affecting the results. Therefore, unlike the other study, in this study i) the opinion of the forest rangers was included, ii) forestry activities were elaborated upon on the basis of the subject, and iii) the priority ranking of the activities was realized with the linear combination technique.

\section{Material and Methods}

The Denizli Forest Enterprise Directorate was chosen as the study area because it covers almost all forestry activities in the Aegean region in Turkey (Fig. 1). In the study, the departments working on forestry in the Denizli Forest Enterprise Directorate and the activities carried out in these departments

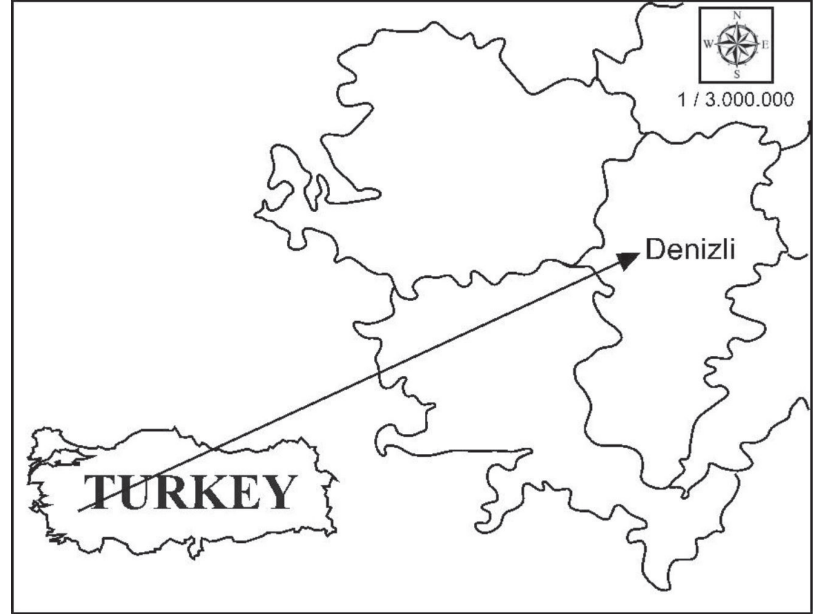

Fig. 1. Study Area (Denizli Forestry Operation Directorate).

were determined at first. Then, seasonal questionnaire forms were prepared, taking into consideration the departments and departmental activities for each season. 24 forest rangers working in the Denizli Forest Enterprise Directorate in 2016 attended to the survey. The autumn questionnaire was answered in October, the winter questionnaire in January, the spring questionnaire in April, and the summer questionnaire in July.

\section{Ranking Technique}

The ranking technique was used to rank the values of forestry activities and to determine the relative seasonal priority of the forestry activities performed in each department. A nine-point scale was utilized to determine the priority given to each forestry activity on a seasonal basis. On this scale, -1- is unimportant while -9- is considered to be very important. In this regard, taking into consideration the objectives of the Denizli Forest Enterprise Directorate, forest rangers gave a priority value between $1-9$ points to the forestry activities.

For example, a forest ranger (k), gave a priority value (j) in the form of $r_{j k 1}, r_{j k 2}, r_{j k 3}, r_{j k m}$, to the activities in the forestry department. Accordingly, the relative priority value $\left(X_{j i}\right)$ of the activities (i) of the forestry department (j) was calculated using the ranking technique in Formula 1 as follows [12]:

$$
X_{j i}=\frac{\sum_{k} r_{j k i}}{\sum_{i} \sum_{k} r_{j k i}}(i=1,2, \ldots, m)
$$

\section{Linear Combination Technique}

In the linear combination technique, the relative priority values of forestry departments and the relative priority values of forestry activities performed in the departments are multiplied. Thus, the relative priority values on both sides are made comparable to 
each other on the same scale [12]. When the priority values obtained by the linear combination technique are sorted, the ranking of forestry activities, which are prioritized by forest rangers, is achieved. The linear equality used in this technique is represented in Formula 2:

$$
P_{j i}=\sum_{i=1}^{m} X_{j i} W_{j i}(i=1,2, \ldots, m) ;(j=1,2, \ldots, n)
$$

Here,

$P_{j i}=$ The final priority value of the activity (i) in the department (j)

$W_{j i}=$ The relative priority value of the department (j) in the department (i)

$X_{j i}=$ The relative priority value of the activity (i) in the department (j)

In this study, the following phases were observed in the analysis through the linear combination technique with the ranking technique.

- Step 1. Forestry departments were compared to each other. Then, with the ranking technique, the relative priority values of each department were obtained.

- Step 2. Forestry activities in the departments were compared with each other. Then, with the ranking technique, the relative priority values of each activity were obtained.

- Step 3. The priority values of each department were multiplied by the priority value of the forestry activities in the departments.

- Step 4. The final priority value of each activity was determined.

\section{Results and Discussion}

In the first step, the forest rangers assessed 7 forestry departments separately on a seasonal basis with ranking technique. Thus, the order of priority values of the departments was reached (Table 1). The highest priority is given to the production and marketing department activities in autumn and winter and to the silviculture department activities in the spring and to the forest fires combating department activities in the summer. Activities of the non-wood forest products and services department are given the least priority in all seasons compared to the other departments.

The priority values given in the general column were calculated by taking the arithmetic mean of seasonal priority points assigned to the forestry departments by forest rangers. Accordingly, with the priority score of 0.1653 , the production and marketing department is considered to be the most important department. This is followed by the silviculture department with 0.1590 priority points and the forest fire combating department with 0.1527 priority points.

In the second step, forest rangers evaluated the activities of forestry departments separately on a seasonal basis with the ranking technique. Accordingly, the priority values of the calculated department activities are presented in Table 2 .

In the third step, the priority value of the relevant department (Table 1) obtained in the first step and the seasonal priority values of the department activities obtained in the second step were multiplied separately in accordance with the linear combination technique. Thus, the final priority value of each activity was obtained on a seasonal basis, called the fourth step (Table 3).

In this study, within the scope of management purposes, we tried to determine at what level the forest rangers prioritize forestry activities and in which season. The most prioritized activities are forestation, silviculture and production and marketing department activities in autumn, winter and spring. Priority in summer is given to combating forest fires. The lowest priority is generally given to the activities in the nonwood forest products and services department. As can be seen here, priorities of forestry activities vary according to the seasons.

As a result of this study, the activities in the nonwood products and services department were cited as the forestry activity given the least priority by forest rangers. Similarly, in the study of Şafak and Gül [11],

Table 1 . Priority values of departments.

\begin{tabular}{|c|c|c|c|c|c|}
\hline \multirow{2}{*}{ Departments } & \multicolumn{5}{|c|}{ Seasons } \\
\cline { 2 - 6 } & Autumn & Winter & Spring & Summer & General \\
\hline Afforestation & 0.1559 & 0.1608 & 0.1579 & 0.1207 & 0.1485 \\
\hline Silviculture & 0.1618 & 0.1652 & 0.1663 & 0.1444 & 0.1590 \\
\hline Production and Marketing & 0.1657 & 0.1784 & 0.1621 & 0.1595 & 0.1653 \\
\hline Planning & 0.1131 & 0.1344 & 0.1158 & 0.1401 & 0.1255 \\
\hline Forest Fire Combating & 0.1540 & 0.1278 & 0.1411 & 0.1853 & 0.1527 \\
\hline Forest Pest Combating & 0.1404 & 0.1322 & 0.1558 & 0.1379 & 0.1423 \\
\hline Non-Wood Forest Products and Services & 0.1092 & 0.1013 & 0.1011 & 0.1121 & 0.1067 \\
\hline
\end{tabular}


Table 2. Priority values of Department activities.

\begin{tabular}{|c|c|c|c|c|c|c|}
\hline \multirow{2}{*}{ Code } & \multirow{2}{*}{ Activities } & \multicolumn{5}{|c|}{ Seasons } \\
\hline & & Autumn & Winter & Spring & Summer & General \\
\hline \multicolumn{7}{|c|}{ Afforestation } \\
\hline $\mathrm{C} 1$ & Erosion control and soil conservation activities & 0.1731 & 0.1952 & 0.1785 & 0.1389 & 0.1719 \\
\hline $\mathrm{C} 2$ & Etude project activities & 0.0866 & 0.0843 & 0.0915 & 0.1194 & 0.0944 \\
\hline $\mathrm{C} 3$ & Nursery activities & 0.1025 & 0.0964 & 0.1030 & 0.1250 & 0.1065 \\
\hline $\mathrm{C} 4$ & Main forest tree species afforestation activities & 0.1936 & 0.2000 & 0.1830 & 0.1806 & 0.1889 \\
\hline $\mathrm{C} 5$ & Rangeland improvement activities & 0.1139 & 0.1205 & 0.1259 & 0.1222 & 0.1211 \\
\hline C6 & Private afforestation activities & 0.1595 & 0.1542 & 0.1556 & 0.1611 & 0.1574 \\
\hline $\mathrm{C} 7$ & Fast growing species afforestation activities & 0.1708 & 0.1494 & 0.1625 & 0.1528 & 0.1598 \\
\hline \multicolumn{7}{|c|}{ Silviculture } \\
\hline $\mathrm{C} 8$ & Rehabilitation activities of degraded forests & 0.1347 & 0.1269 & 0.1245 & 0.1187 & 0.1265 \\
\hline C9 & Fire resistant species facility project activities & 0.1442 & 0.1383 & 0.1305 & 0.1233 & 0.1345 \\
\hline $\mathrm{C} 10$ & Natural generation activities & 0.1594 & 0.1629 & 0.1667 & 0.1644 & 0.1627 \\
\hline $\mathrm{C} 11$ & Artificial regeneration activities & 0.1480 & 0.1458 & 0.1486 & 0.1530 & 0.1486 \\
\hline $\mathrm{C} 12$ & Activities of care of regeneration and cultivation & 0.1499 & 0.1591 & 0.1626 & 0.1598 & 0.1586 \\
\hline $\mathrm{C} 13$ & Precommercial thinning care activities & 0.1613 & 0.1572 & 0.1647 & 0.1781 & 0.1647 \\
\hline $\mathrm{C} 14$ & Pruning activities & 0.1025 & 0.1098 & 0.1024 & 0.1027 & 0.1044 \\
\hline \multicolumn{7}{|c|}{ Production and Marketing } \\
\hline $\mathrm{C} 15$ & Activity of tree marking & 0.1507 & 0.1549 & 0.1537 & 0.1464 & 0.1521 \\
\hline $\mathrm{C} 16$ & Determination of timber production costs & 0.1436 & 0.1362 & 0.1442 & 0.1407 & 0.1410 \\
\hline $\mathrm{C} 17$ & Supervision of timber production activities & 0.1489 & 0.1455 & 0.1518 & 0.1578 & 0.1503 \\
\hline $\mathrm{C} 18$ & Activities for standing timber sales & 0.1526 & 0.1622 & 0.1557 & 0.1501 & 0.1558 \\
\hline C19 & Activities for sale of forestry products & 0.1152 & 0.1213 & 0.1290 & 0.1369 & 0.1262 \\
\hline $\mathrm{C} 20$ & Activities for transport of forestry products & 0.1472 & 0.1530 & 0.1461 & 0.1426 & 0.1466 \\
\hline $\mathrm{C} 21$ & Stock activities carried out in forest storage yard & 0.1418 & 0.1269 & 0.1195 & 0.1255 & 0.1280 \\
\hline \multicolumn{7}{|c|}{ Planning } \\
\hline $\mathrm{C} 22$ & Forest management plan implementation activities & 0.1688 & 0.1598 & 0.1542 & 0.1737 & 0.1638 \\
\hline $\mathrm{C} 23$ & Writing of stand activities on compartment cards & 0.1396 & 0.1515 & 0.1315 & 0.1455 & 0.1419 \\
\hline $\mathrm{C} 24$ & Plan change activities & 0.1354 & 0.1266 & 0.1293 & 0.1197 & 0.1288 \\
\hline $\mathrm{C} 25$ & Activities for determination of the allowable cut & 0.1375 & 0.1575 & 0.1610 & 0.1268 & 0.1463 \\
\hline $\mathrm{C} 26$ & Activities for the stand tending program & 0.1666 & 0.1535 & 0.1587 & 0.1479 & 0.1572 \\
\hline $\mathrm{C} 27$ & Unregulated felling activities & 0.1458 & 0.1494 & 0.1474 & 0.1620 & 0.1506 \\
\hline $\mathrm{C} 28$ & National park and protection forest planning activities & 0.1063 & 0.1017 & 0.1179 & 0.1244 & 0.1114 \\
\hline \multicolumn{7}{|c|}{ Forest Fire Combating } \\
\hline $\mathrm{C} 29$ & Surveillance, supervision and control activities & 0.1455 & 0.1546 & 0.1600 & 0.1531 & 0.1535 \\
\hline $\mathrm{C} 30$ & Extinguishing and cooling activities & 0.1584 & 0.1452 & 0.1726 & 0.1664 & 0.1616 \\
\hline $\mathrm{C} 31$ & Air vehicle activities & 0.1326 & 0.1241 & 0.1053 & 0.1191 & 0.1212 \\
\hline $\mathrm{C} 32$ & Activities related to first intervention teams & 0.1418 & 0.1522 & 0.1431 & 0.1493 & 0.1455 \\
\hline $\mathrm{C} 33$ & Communication activities & 0.1436 & 0.1616 & 0.1516 & 0.1437 & 0.1495 \\
\hline $\mathrm{C} 34$ & Reducing flammable substances on roadsides & 0.1400 & 0.1194 & 0.1495 & 0.1474 & 0.1394 \\
\hline
\end{tabular}


Table 2. Continued.

\begin{tabular}{|c|c|c|c|c|c|c|}
\hline $\mathrm{C} 35$ & Determining forest fire costs & 0.1381 & 0.1429 & 0.1179 & 0.1210 & 0.1293 \\
\hline \multicolumn{7}{|c|}{ Forest Pest Combating } \\
\hline $\mathrm{C} 36$ & Activities for the determination of forest crimes & 0.1805 & 0.1767 & 0.1656 & 0.1663 & 0.1723 \\
\hline C37 & Activities for seized crime tools & 0.1515 & 0.1559 & 0.1532 & 0.1422 & 0.1511 \\
\hline $\mathrm{C} 38$ & Checking grazing areas & 0.1328 & 0.1268 & 0.1408 & 0.1291 & 0.1324 \\
\hline C39 & Activities related to protection teams & 0.1473 & 0.1435 & 0.1512 & 0.1488 & 0.1471 \\
\hline $\mathrm{C} 40$ & Activities for forest pests combating & 0.1535 & 0.1455 & 0.1573 & 0.1751 & 0.1576 \\
\hline C41 & ICP forest program activities & 0.1141 & 0.1206 & 0.1056 & 0.1160 & 0.1134 \\
\hline $\mathrm{C} 42$ & Training activities in the forest pests combating & 0.1203 & 0.1310 & 0.1263 & 0.1225 & 0.1261 \\
\hline \multicolumn{7}{|c|}{ Non-Wood Forest Products and Services } \\
\hline $\mathrm{C} 43$ & Activities for urban forest & 0.1366 & 0.1538 & 0.1294 & 0.1144 & 0.1325 \\
\hline $\mathrm{C} 44$ & Forest recreation area activities & 0.1481 & 0.1346 & 0.1443 & 0.1692 & 0.1500 \\
\hline $\mathrm{C} 45$ & Hunting and wildlife activities & 0.1319 & 0.1676 & 0.1169 & 0.1294 & 0.1350 \\
\hline $\mathrm{C} 46$ & Inventory activities & 0.1134 & 0.1126 & 0.1318 & 0.1095 & 0.1175 \\
\hline $\mathrm{C} 47$ & Activities for production of medicinal aromatic plants & 0.1598 & 0.1401 & 0.1642 & 0.1542 & 0.1550 \\
\hline $\mathrm{C} 48$ & Activities for mushroom production & 0.1528 & 0.1484 & 0.1791 & 0.1716 & 0.1625 \\
\hline $\mathrm{C} 49$ & Activities for the establishment of honey forest & 0.1574 & 0.1429 & 0.1343 & 0.1517 & 0.1475 \\
\hline
\end{tabular}

Table 3. Priority values of activities.

\begin{tabular}{|c|c|c|c|c|c|c|c|c|c|c|}
\hline \multirow{2}{*}{ Code } & \multicolumn{2}{|c|}{ Autumn } & \multicolumn{2}{|c|}{ Winter } & \multicolumn{2}{|c|}{ Spring } & \multicolumn{2}{|c|}{ Summer } & \multicolumn{2}{|c|}{ General } \\
\hline & Score & No & Score & No & Score & No & Score & No & Score & No \\
\hline $\mathrm{C} 1$ & 0.0270 & 2 & 0.0314 & 2 & 0.0282 & 2 & 0.0168 & 34 & 0.0255 & 5 \\
\hline $\mathrm{C} 2$ & 0.0135 & 40 & 0.0136 & 43 & 0.0144 & 42 & 0.0144 & 40 & 0.0140 & 44 \\
\hline $\mathrm{C} 3$ & 0.0160 & 34 & 0.0155 & 37 & 0.0163 & 37 & 0.0151 & 36 & 0.0158 & 40 \\
\hline $\mathrm{C} 4$ & 0.0302 & 1 & 0.0322 & 1 & 0.0289 & 1 & 0.0218 & 18 & 0.0281 & 1 \\
\hline $\mathrm{C} 5$ & 0.0178 & 26 & 0.0194 & 26 & 0.0199 & 26 & 0.0147 & 38 & 0.0180 & 31 \\
\hline C6 & 0.0249 & 8 & 0.0248 & 9 & 0.0246 & 11 & 0.0194 & 24 & 0.0234 & 14 \\
\hline $\mathrm{C} 7$ & 0.0266 & 3 & 0.0240 & 12 & 0.0257 & 7 & 0.0184 & 27 & 0.0237 & 12 \\
\hline $\mathrm{C} 8$ & 0.0218 & 18 & 0.0210 & 19 & 0.0207 & 24 & 0.0171 & 31 & 0.0201 & 25 \\
\hline C9 & 0.0233 & 15 & 0.0228 & 14 & 0.0217 & 20 & 0.0178 & 28 & 0.0214 & 20 \\
\hline $\mathrm{C} 10$ & 0.0258 & 5 & 0.0269 & 6 & 0.0277 & 3 & 0.0237 & 11 & 0.0259 & 3 \\
\hline $\mathrm{C} 11$ & 0.0239 & 12 & 0.0241 & 11 & 0.0247 & 10 & 0.0221 & 17 & 0.0236 & 13 \\
\hline $\mathrm{C} 12$ & 0.0242 & 11 & 0.0263 & 7 & 0.0270 & 5 & 0.0231 & 13 & 0.0252 & 6 \\
\hline $\mathrm{C} 13$ & 0.0261 & 4 & 0.0260 & 8 & 0.0274 & 4 & 0.0257 & 6 & 0.0262 & 2 \\
\hline $\mathrm{C} 14$ & 0.0166 & 31 & 0.0181 & 31 & 0.0170 & 34 & 0.0148 & 37 & 0.0166 & 35 \\
\hline $\mathrm{C} 15$ & 0.0250 & 7 & 0.0276 & 4 & 0.0249 & 9 & 0.0234 & 12 & 0.0251 & 7 \\
\hline $\mathrm{C} 16$ & 0.0238 & 13 & 0.0243 & 10 & 0.0234 & 17 & 0.0224 & 16 & 0.0233 & 15 \\
\hline $\mathrm{C} 17$ & 0.0247 & 9 & 0.0260 & 8 & 0.0246 & 11 & 0.0252 & 7 & 0.0248 & 8 \\
\hline $\mathrm{C} 18$ & 0.0253 & 6 & 0.0289 & 3 & 0.0252 & 8 & 0.0239 & 10 & 0.0258 & 4 \\
\hline C19 & 0.0191 & 23 & 0.0216 & 16 & 0.0209 & 23 & 0.0218 & 18 & 0.0209 & 23 \\
\hline
\end{tabular}


Table 3. Continued.

\begin{tabular}{|c|c|c|c|c|c|c|c|c|c|c|}
\hline $\mathrm{C} 20$ & 0.0244 & 10 & 0.0273 & 5 & 0.0237 & 15 & 0.0227 & 15 & 0.0242 & 11 \\
\hline C21 & 0.0235 & 14 & 0.0226 & 15 & 0.0194 & 28 & 0.0200 & 22 & 0.0212 & 22 \\
\hline $\mathrm{C} 22$ & 0.0191 & 23 & 0.0215 & 17 & 0.0179 & 32 & 0.0243 & 8 & 0.0206 & 24 \\
\hline $\mathrm{C} 23$ & 0.0158 & 35 & 0.0204 & 22 & 0.0152 & 38 & 0.0204 & 21 & 0.0178 & 33 \\
\hline $\mathrm{C} 24$ & 0.0153 & 37 & 0.0170 & 33 & 0.0150 & 39 & 0.0168 & 34 & 0.0162 & 37 \\
\hline $\mathrm{C} 25$ & 0.0156 & 36 & 0.0212 & 18 & 0.0186 & 29 & 0.0178 & 28 & 0.0184 & 30 \\
\hline C26 & 0.0188 & 24 & 0.0206 & 21 & 0.0184 & 30 & 0.0207 & 19 & 0.0197 & 26 \\
\hline $\mathrm{C} 27$ & 0.0165 & 32 & 0.0201 & 23 & 0.0171 & 33 & 0.0227 & 15 & 0.0189 & 27 \\
\hline C28 & 0.0120 & 42 & 0.0137 & 42 & 0.0137 & 43 & 0.0174 & 29 & 0.0140 & 44 \\
\hline C29 & 0.0224 & 16 & 0.0198 & 24 & 0.0226 & 18 & 0.0284 & 2 & 0.0234 & 14 \\
\hline C 30 & 0.0244 & 10 & 0.0186 & 29 & 0.0244 & 13 & 0.0308 & 1 & 0.0247 & 9 \\
\hline C31 & 0.0204 & 22 & 0.0159 & 35 & 0.0149 & 40 & 0.0221 & 17 & 0.0185 & 29 \\
\hline C32 & 0.0218 & 18 & 0.0195 & 25 & 0.0202 & 25 & 0.0277 & 3 & 0.0222 & 18 \\
\hline C33 & 0.0221 & 17 & 0.0207 & 20 & 0.0214 & 21 & 0.0266 & 5 & 0.0228 & 16 \\
\hline C34 & 0.0216 & 19 & 0.0153 & 38 & 0.0211 & 22 & 0.0273 & 4 & 0.0213 & 21 \\
\hline C35 & 0.0213 & 20 & 0.0183 & 30 & 0.0166 & 35 & 0.0224 & 16 & 0.0197 & 26 \\
\hline C36 & 0.0253 & 6 & 0.0233 & 13 & 0.0258 & 6 & 0.0229 & 14 & 0.0245 & 10 \\
\hline C37 & 0.0213 & 20 & 0.0206 & 21 & 0.0239 & 14 & 0.0196 & 23 & 0.0215 & 19 \\
\hline C38 & 0.0186 & 25 & 0.0168 & 34 & 0.0219 & 19 & 0.0178 & 28 & 0.0188 & 28 \\
\hline C39 & 0.0207 & 21 & 0.0190 & 28 & 0.0236 & 16 & 0.0205 & 20 & 0.0209 & 23 \\
\hline C40 & 0.0216 & 19 & 0.0192 & 27 & 0.0245 & 12 & 0.0241 & 9 & 0.0224 & 17 \\
\hline C41 & 0.0160 & 34 & 0.0159 & 35 & 0.0165 & 36 & 0.0160 & 35 & 0.0161 & 38 \\
\hline $\mathrm{C} 42$ & 0.0169 & 29 & 0.0173 & 32 & 0.0197 & 27 & 0.0169 & 33 & 0.0179 & 32 \\
\hline $\mathrm{C} 43$ & 0.0149 & 38 & 0.0156 & 36 & 0.0131 & 46 & 0.0128 & 41 & 0.0141 & 43 \\
\hline C44 & 0.0162 & 33 & 0.0136 & 43 & 0.0146 & 41 & 0.0190 & 26 & 0.0160 & 39 \\
\hline C45 & 0.0144 & 39 & 0.0170 & 33 & 0.0118 & 47 & 0.0145 & 39 & 0.0144 & 42 \\
\hline C46 & 0.0124 & 41 & 0.0114 & 44 & 0.0133 & 45 & 0.0123 & 42 & 0.0125 & 45 \\
\hline C47 & 0.0175 & 27 & 0.0142 & 41 & 0.0166 & 35 & 0.0173 & 30 & 0.0165 & 36 \\
\hline C48 & 0.0167 & 30 & 0.0150 & 39 & 0.0181 & 31 & 0.0192 & 25 & 0.0173 & 34 \\
\hline C49 & 0.0172 & 28 & 0.0145 & 40 & 0.0136 & 44 & 0.0170 & 32 & 0.0157 & 41 \\
\hline
\end{tabular}

where the evaluation was made by forest engineers, the activities of this department were given the least priority. The main reason for this result is the low tariff price for non-wood forest products.

In the study of Şafak and Gül [11], forest engineers gave the most priority to combating and preventing forest fires, as well as silviculture activities in 2011. The present study also resulted in similar ways. The production and marketing department are given the most priority in autumn and winter, similarly the silviculture department in the spring, and the forest fire-combating department in the summer, compared to the other departments.
Forest engineers are executive in forest enterprises, and forest rangers serve as auxiliary technical personnel. These individuals have different duties and responsibilities for forestry activities, affecting the level of priority given to the activities. For this reason, forest rangers gave less priority to the activities that are the responsibility of engineers. For example, forest rangers attributed low priority to the activities such as etude project (C2), inventory (C46), and national park and protection forest planning (C28), which are not in their direct responsibility.

Maier and Winkel [5] stated that the personality characteristics of forest rangers can be sorted as four 
types: multi-functional, protectionist, public servant and production-oriented. These characteristics are similar to the characteristics of forest rangers working in different departments with different knowledge and experience in Turkey.

Forest rangers, as stated by Alkan and Uğur [8], graduate with associate degrees, which includes various expertise areas such as forest management, hunting and wildlife, arboriculture, and non-wood forest products. However, the departments where forest rangers are employed in forest enterprises are not usually related to their associate degree. However, as stated by An et al. [13], forest rangers trained in the fields of forestry, agriculture, and fisheries perform the duties in a more qualified manner when assigned to protect wetlands. In other words, employing forest rangers in departments related to associate degree education will enable them to specialize and increase productivity.

\section{Conclusions}

In forest enterprises, jobs are grouped with names such as department, unit, and sub-unit so that activities can be effectively executed. Drawing the boundaries of these groups and defining their duties are important for the effectiveness of forestry activities. In this context, assessments aimed at determining the activities carried out in forest enterprises on the basis of years and periods are important for sustainable forest management.

The priority ranking of the activities obtained through this research reveals essentially the prioritized objectives of Denizli Forest Enterprise Directorate. In addition, this ranking allows for the evaluation of the intelligibility of management purposes by forest rangers. In the future, key roles at the organizational level for the planning, design, and development of forestry organization can be compared more concretely with these study conclusions.

\section{Acknowledgements}

In this study, the data of the project was obtained by using the Job Analysis of Denizli Forest Enterprise Directorate. We would like to thank the General Directorate of Forestry and Aegean Forestry Research Institute for their support.

\section{Conflict of interest}

The authors declare no conflict of interest.

\section{References}

1. ANONYMOUS. Regulation on the duties and working principles of forest custodians, Ministry Approval No: 4, Ministry Approval Date: 06.03.1996.

2. YILMAZ, E., ERPULAT, M., ALKAN, S., GÜLER, K. H., KOŞDEMIR, Z. Workload analysis of forest rangers in western Mediterranean region. Southwest Anatolia Forest Research Institute, 2017.

3. KUVAN Y., EROL S.Y., YILDIRIM H.T. Forest managers' perceptions of the foremost forestry issues and functions in Turkey. Polish Journal of Environmental Studies. 20 (2), 393, 2011.

4. ŞAFAK I., GÖKSU E. Determination of job diversity at forest district directorates in Turkey: a case study of Denizli Forest District Directorate. Journal of Forestry Research. 1 (4), 114, 2016.

5. MAIER C., WINKEL G. Nature conservation through integrated forest management: A street-level bureaucracy perspective on the German public forest sector. Forest Policy and Economics. 82, 14, 2017.

6. ELVAN D. Authorities and duties of general security forces for protection of forests. Journal of the Faculty of Forestry Istanbul University. 55 (1), 85, 2005.

7. ÖZTÜRK A. A study on the problems of forest rangers. Artvin Çoruh University Journal of Forestry Faculty. 14 (2), 253, 2013

8. ALKAN H., UĞUR G.E. Analysis related to the technical assistant staff problem in forestry. Turkish Journal of Forestry. 17 (2), 132, 2016.

9. CHOU J.R. A weighted linear combination ranking technique for multi-criteria decision analysis. South African Journal of Economic and Management Sciences, Special Issue, 16 (5), 28, 2013.

10. KHADKA C., VACIK H. Use of multi-criteria analysis (MCA) for supporting community forest management. iForest. 5, 60, 2012.

11. ŞAFAK İ., GÜL A. U. Evaluation of importance given to the functions of forests and forestry activities by forest engineers. Turkish Journal of Forestry. 13 (2), 123, 2012.

12. YILMAZ E. The R'WOT technique; case study of a participatory approach to beekeeping sector. Eastern Mediterranean Forestry Research Institute. Release No: 40. Tarsus. 2006.

13. AN L.T., MARKOWSKI J., BARTOS M. The comparative analyses of selected aspects of conservation and management of Vietnam's national parks. Nature Conservation. 25, 1, 2018. 
